the best anæsthetic for this purpose. It is less poisonous than bromethyl, and any disagreeable post-operative symptoms, e.g. sickness, are rare.

H. E. G. Boyle, in a paper on this sulject communicated to the Abernethian Society, December 3, 1903, based his observations on 500 administrations of somnoform for various surgical operations; 200 of these were for the removal of tonsils and adenoids. Boyle is of the opinion that for this operation somnoform, properly and judiciously administered, possesses advantages which cannot he orerlooked. The duration of anesthesia is amply sufficient for the removal of either tonsils or adenoids, and in most cases, and expecially in children, gives enough time for the removal of both. Moreorer the after-effects, or rather the absence of after-effects, he has found to be particularly encouraging.

In a brief summary of the year's work it is difficult to enter into many details of the new work, or of the derelopment of the work of previous years, but enough has been said to show that the past year has been one of progress in this special department of practice.

\title{
RETROSPECT OF OTOLOGY, 1903.
}

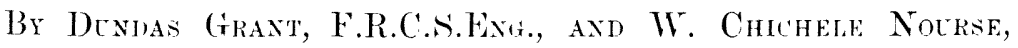 \\ F.R.C.A.Enf.
}

1) Cring the year now expired otolngists at home and abroad have occupied themselves with steady progress along the established ines rather than by breaking new ground in any very striking directions. Among the most progressive features of the year may be noted the tendency to include the labyrinth as within the range of surgical intervention. Hinsherg has given a rery exhanstive account of it, and Lermoyez, acknowledging the influence of Hinsberg's inspiration, has in his usual lucid manner prepared a condensed and clarified statement of our present knowlerge of suppuration of the labyrinth. The subject is to be discussed at the International Otolngical Congress at Bordeaux this year. Professor Denker has reviewed the history of our knowledge of sclerosis of the middle ear. Patholngy is in regard to this distresing affection far ahead of therapeutice. We must hope in the future for new light on this also. Professors Bezold and Ostmann have 
still further added to our knowledge of the "functional" tests, as will be seen in the following condensed retrospect. The numbers refer to the pages of the volume of the Jocrnal or Larysiology for 1903 .

Meatus.-Three cases of (mengital Atresia with Microtia are recorded by Jürgens (.5)7). At the British Laryngological and Otological Association Wingrave (416) showed microscopic specimens of Cenuminous Glands. Otomycosis in the Malay Arrlipelugo, where it is exceedingly common, forms the subject of an interesting paper by (ialloway, of Singapore (64). At the Otological Society of the United Kingdom Tilley (85) exhibited a patient from whom he had removed a large hyperostosis. The co-existence of suppuration had necessitated the performance of a radical mastoid operation. The discussion which followed chiefly turned upon the value of grafting.

Membrane axb Ossicles.-At the American Laryngological, Rhinological, and Otological Society Roy $(607)$ discussed the value of Exploratory Puncture of the Membrane, Dench (611) writes upon Osxiculectomy, Clarence Blake (108) on Tenxion Anomalits of the Sonnd-tinsmitting Apparatus, and advocates exploratory tympanotomy as an aid to diagnosis. He points out the liahility to relaxation of the membrane from the excessive nse of the varions instruments for pneumo-massage of the tympanmm.

Chronic Non-scpulcative Catarrh of the Mrnde Ear.-Hopkins (5.3) recommends the use of superheated compressed air as an adjunct to other treatment in suitable cases. Stoker (111) found ozone of value when introduced throngh the Eustachian tube. At the Otological Society of the United Kingdom Philip) Nelson (36:3) showed cases of the upper and lower jaw from a case of Chronic Middle-ear Catarh. Dundas (irant (20:34) published a lecture upon the Varieties of Chomic Non-suplunative Diserese of the Middle Ear, in which the distinctive features of otosclerosis are described. It the German Otological Society Denker also (4.51) read a valuable report upon Ankylosis of the Strups. At the American Laryngological, Rhinological, and Otological Society (Goldstein (600) read a paper on the Use and Abuse of the Enstachiun Bungis; at the same society Duel (60) communicated a paper upon the Elostrolytic Bongie in Caturhal Deafurss. It seems probable that in the same skilled hands equally good effects might have resulted from the nise of a simple bongie.

Accte Scpreration of the Mrmene Ear.-The treatment of this affection is discussed, and the value of early paracentesis unanimously emphasised, by (iomper\% (109), who also alludes to 
the treatment of persistent perforatious by trichlor-acetic acid, and to the use of artificial ear-drums. Meierhoff (111) and Phillips (22.3) have also written on this affection. Schroeder (276) records two severe cases caused by the use of "Schneeberger" snuff. Leaven (612) draws attention to the extraordinary frequency of unrecognised otitis media in young children. Klug (558) believes that acute otitis is often infectious, and advises isolation, but Wolff (5).)9), on the other hand, declares that it is not contagious unless secondary to a contagious disease.

Daxgerols Sequela of Stppuration of the Middle Ear.-Numerons important contributions have been made with regard to $E n$ (chullic Abscesses, Meningitis, and (stitic Pyæmia. We may refer to those by Reverdin and Vallette (5), Claude Douglas (109), A. Knapp (110), Gillet (442), R. M. Simon (447), Gaudier (411), Andrew (501) -all cases of Cerelyellar Abscess, several yielding instructive autopsies. Cases of C'erpbral Alscess seem to have been fewer, Brunard and Labarre (440) and Hugh Jones (363) being among the small number of contributors. In some there was naturally a coincident meningitis. Meningitio, with a report on the cyto-diagnosis, is recorded by Ledoux (390). Otitir Pyania is illustrated by two cases reported by Norval Pierce (593), in which there was thrombosis of the jugular bulb, requiring ligature of the internal jugular. Pift (46) describes his method of exposing the bulb of the jugular vein. Schiffer (4t6) narrates a case of Thrombosis of the Caremous Sinus; Enlenstein (109) one of Temporal Bone Toxamia; and Breyne (334) one of Otitic Pyamia.

Chronic Supplaterfe Catarrh. - A symposium of papers was presented at the American Laryngological, Rhinological, and Otological Society. Pierce (550), who opened the discussion, dealt with the etiology and pathology; Richardson (5.50) also treated the same parts of the subject; and McKernon (5.52) read a paper upon the treatment of complications. A large amount of study has been devoted to the same subject by other observers, which will be alluded to under the heading of "mastoid operations."

Mas'ton Diseases.-Dum (166) describes a small space on the under surface of the mastoid process, under the name of the inferior occipital plate, through which it is probable that perforation takes place in some cases of Bezold's mastoiditis. The same author' (2.23) describes a case of Acute Suppuration of the Mastoid Cells involving neither the middle ear nor the antrum. Snow (613) adrocates conservatiom in the treatment of acute mastojidis. At the Otological Society of the United Kingdom Lee (357) showed 
a case of Acute Otitis Media and Antrum Disense, and Permewan (361) one of Mastoid Suppuration with Intrateranial Alscess, lnut without Perforation of the Membrana Tympani. In the discussion which followed, Ballance and Whitehead mentioned somewhat similar cases. Fagge thought that in such cases the infection might be pneumococeal. Secord (277) describes a case of Erophthrilmos following Mastoiditiv. Trow (61:3) records a case of Mastoiditis due to (ronsenecus. Bert Fillis (592), at the American Laryngological, Rhinological, and Otological Society, reported some unusual mastoid cases. Kamm (390) records a case of Arut. Mastoiditis, in which a swelling extending downwards below the mastoid process proved to be due to scleroderma.

The Mastom, Operation.-Lenoir (166) treats of the Value of the Supra-meatal Spine as an Operation Landmark in Pationts ocer the age of ten years. In younger children, where the spine is absent, there is a rascular spot, the "tache spongieuse," which covers the site of the antrum and will serve as a guide. The variations in the course of the facial nerve have been studied by Schwartze (277) and Randall (335). The surgical relations of this nerve have been discussed by Jones (294), in a brief but valuable paper. At the Otological Society of the United Kingdom Dundas Grant (84) showed a case of Cholestertoma of the Attic and Antrum in which he had carried out the radical operation, leaving the matrix, with a successful result. At the British Laryngological, Rhinological, and Otological Association Grant (209) also showed a case of Chulestentoma which he had operated on with grafting, having as an exceptional proceeding turned out the cholesteatoma with its entire matrix. The Ajtertreatment of Radical Operations withont Pacling formed the subject of a paper by Zur Muehlen (613), and was discussed by Lermoye (35:) at the International Medical Congress at Madrid. Milligan (3.58), at the Otological Society, showed two cases of chronic Suppurative Middle-er Disense ; a discussion chiefly upon the after-treatment without tampon followerl. Tilley refered to Heath's early instillation of alcoluel. Knapp and Jordan (445) give a report of forty ratical mastoil operations. Ray (551) condemns Wilde's incision. Moestig-Moorhof (392) describes an imbtom stopling for filling cavities in bones which might prove of use in some mastoid operations. Chevalier Jackson (389), writing upon the Ratical Mastoid Opreratims, discusses the causes of failure, and describes some details of the operation as performed by him. At the American Laryngological, Rhinological, and ()tological Society Dench (590) rearl a paper on the Technique of 
the Radical Mastuid Operation. A similar subject-namely, the Technique of Operations on the Temporal Bone in Suppurative Middle-ear Disease-formed the subject of a discussion in the section of laryngology and otology at the annual meeting of the British Medical Association. It was opened by McBride (513) with a detailed description of the history of the operation, and by Hartmann (531), who dealt with some points of interest in the operation, and with the treatment of labyrinthine suppuration.

Deaf-sutiss. - A joint meeting of the Otological Society of the United Kingdom and the National Association for Teachers of the Deaf was held in July last, when a discussion upon the Methorl of Dealing with and Developing the Residual Hearing Power and Spepch of the Deaf was opened by Kerr Love (393) and W. Permewan. At the International Medical Congress at Madrid the Canses of Deaf-mutism were discussed by Schmiegelow (347) and Castex (348). Gutzmann (347) also drew attention to the irregular respiration of deaf mutes during speech.

Ixtersil bar.-Among the mont striking communications on Suppuration in the Laly,rinth are that of Hinsherg (4+3), founded on sixty-one cases, and that of $\mathbf{X}$ ooure (351). Hugh Jones (77) showed a Sequestrum from a Suljoct of Hereditary Syphilis. Manasse (391) deals with the P'athology of the Internal Ear and Auditory Yore. Nores-deafiness due to Tobacen is fully studied by Wingrave (172).

Tebercelosis of the Bar. - The epochal discussion on this subjeet held by the Otological society of the United Kingdom contains statements by many British otologists (15.) and 1.58). (Goldstein (113) reports four cases of Primary Tulerculowis of the Ear folloned by Mastriditis. We are indebted for other cases and specimens to Fagge (195), Cheatle (195), and Horne (197), the last contributing a paper on the Clinical Diagnosis and sinrgical Treatmont of Tuber"ulosis of the Temporal Bome (612).

Matignaxt Disease is illustrated by cases described by beanesley, Permewan, Barr, Milligan, Walker, Abbott (7i). A most important communication on a case of Epithelioma of the Widdle Ear (80) comes from A. H. Cheatle, as also one (84) on a Tumour of the Meatus found to be an Endothelioma, and a report (197) on a Slorryrowing Adeno-carcinoma, probably what is now recognised as endothelioma. Cases of Elpithelioma were narrated by Lee (357), (Grant (642), and Permewan (36:3), affecting the auricle, external meatus, and middle ear respectively. Stockdale (363) and Wingrave (645) give histological communications.

Treatment.-Mouret and Denoyes (164) have applied high- 
frequency currents to cases of sclerosing otitis. Delsaux (22:3) describes his experience of adrenalin in otology. Marage (5t) uses an instrument like a syren for exercising the sense of hearing. Koemer (391) contributes an interesting paper on the methods of treatment and operation employed in his clinique. The Operative Treatment of Facial Prelsy is discussed by C. Ballance, H. Ballance, and Purves (501), who conclude that facio-hypoglossal anastomosis is to be recommended rather than facio-accessory. Korte's $\left(446^{2}\right)$ case of Implantation of the Faciol to the Hypoglossal Nerve controverts the correctness of this view, as the discomfort of the patient in regard to feeding at the time when the facial as well as the lingual muscles were paralysed, was almost intolerable. It is probably best to divide the spinal accessory completely and trust to the cervical nerves to keep up the supply to the trapezius.

Tests for Hearina. - At the International Medical Congress at Madrid Struyschen (350) conchudes that more accurate observations can be made upon the minimal degree of hearing as tested by the tuning-fork. At the Otological Society, Wiesbaden, Ostman (561) read a paper upon an objective uniform measure of hearing as supplied by the amplitude of vibration of Edelmann's $C$ and $G$ tuning-forks.

Miscelianeous. - At the Otological Society of the United Kingdom Bromer (83) showed drawings of two cases of retro-auricular opening left after operation treated by paraftin injections. At the same society Baber (87) showed a case of Objective Clicking Tinnitus. Pegler (314) also, at the British Laryngological, Rhinological, and Otological Association, showed a case of Entotic Timitus; and Muck (446) records a case of Entotic Mrurmur due to Aneurysm of the Occipital Artery. Dundas Grant (310 and 641) showed a case of Itrafness due to Myxcedema, with complete recorery of hearing. At the Otological Society of the United Kingdom Campbell (339) read a paper upon Cortical Localisation of the Auditory Area ; and Paterson (404) upon the Der-lopment and Morplology of the Ear. Aderman (386) studies the Variations of the Masto-squamosal Suture. Dowling (276) writes upon the Far Compliations of la Gripue. At the Otological Society of the United Kingdom Cheatle (354 read a paper upon Quinine Deafness and its Precention; it led to an interesting discussion. Somers (558) writes upon the theory of Cross Education as applied to the Auditory Apuaratus. At the American Laryngological, Rhinological, and Otological Society Wendell Phillips (630) read a paper on Life Insurance and Ear Distr.ses, especially in regard to suppurative disease; he considers that chronic foetid discharge indicates that the person so affected 
is a bad life. The radical operation is destined to become an important factor in considering risks. At the same Society Braislin (1332) reported a case of Teratoma of the Ear. Voss (672) noted three cases of Encephalitis associated with Otitis Media.

We have not referred to all the papers on otology which have appeared in full or in abstract in the Joonsar, during the past rear, but we trust we have sufficiently indicated the chief points of novelty and interest.

I) ATES OF GENERAL MEETINGS IN LONDON OE SPECIAL SOCIFIIES DURING 1904.

'lihe Brtish Lakyeglogical, Rhinological, and Otological Astritation, at 11, Chandos Street, Cavendish Square, W., at t p.m. on Friday-January 29, March 11 (annual dinner), May 13, Nivember 11.

'The Larynalogical Socletr of London, at 20, Hanover sipuare, W., at 5 p.m., on Friday-January 15 (annual dinner), February 5, March 4, April 8, May 6, June 3.

The Otological Societr of the Uxited Kingdon, at 11, ('handos Street, Cavendish Square, W., at 4.30 p.m., on Mondays - February 1, March 7, May 2, December 5 (ammual dinner).

\section{SOCIETIES' PROCEEDINGS.}

\section{PROCEEDINGS OF THE GERMAN OTOLOGICAL SOCIETY.}

May 29 and $30,1903$.

\section{INTRA-NASAL OPERATIONS: THE PREPARATORY STEPS AND AFTER-TREATMENT.}

By Dr. G. Krebs, Hildesheim.

Translated ly Dr. Westerman.

(Dinioss do not vary greatly as to the preparations for, and after-treatment in, aural operations, but there is no such conr'nsus of opinion with regard to the steps to be taken before and after an intra-nasal operation. I do not propose in this paper 